\title{
An Aspirational Community Theory of the Firm
}

\author{
$\mathrm{Li}$, Xin
}

Document Version

Final published version

Publication date:

2013

License

CC BY-NC-ND

Citation for published version (APA):

$\mathrm{Li}, \mathrm{X}$. (2013). An Aspirational Community Theory of the Firm. Paper presented at The Academy of Management Annual Meeting 2013, Lake Bueno Vista (Orlando), FL, United States.

Link to publication in CBS Research Portal

\section{General rights}

Copyright and moral rights for the publications made accessible in the public portal are retained by the authors and/or other copyright owners and it is a condition of accessing publications that users recognise and abide by the legal requirements associated with these rights.

\section{Take down policy}

If you believe that this document breaches copyright please contact us (research.lib@cbs.dk) providing details, and we will remove access to the work immediately and investigate your claim. 


\title{
An aspirational community theory of the firm
}

\author{
Xin Li \\ Asia Research Centre, \\ Department of International Economics and Management, \\ Copenhagen Business School, \\ Porcelænshaven 24, \\ 2000 Frederiksberg, \\ Denmark \\ Tele: (0045) 38153406 \\ E-mail: $\underline{x 1 . i n t @ c b s . d k}$
}

A paper presented at the Academy of Management (AOM) 2013 Annual conference

(Paper ID \# 15502)

\begin{abstract}
All of the three major theories of the firm, i.e., the transaction cost theory, knowledgebased theory and the entrepreneurship theory, offer some insightful analyses of the nature of the firm. However, they all have limitations and weaknesses in answering the fundamental question of the existence of the firm. In addition, they are all partial due to their particular focus on the multifaceted phenomenon of the firm. We argue that it is necessary and sufficient to develop a comprehensive yet integrative theory of the firm that combines the three competing yet complementary logics. Toward this end, we propose an aspirational community theory of the firm (ACT) as a candidate theory by conceptualizing the firm as an aspirational community, the core of which is a group of like-minded people sharing similar or same aspiration/vision. To explain the comparative advantage of the firm vis-à-vis market, we make a distinction between contractual labor and aspirational labor, the former being defined as services provided by a laborer in fulfillment of a contract while the latter as services provided by a laborer in pursuit of an aspiration; and argue that firms exist because while the market may be effective and efficient for allocating contractual labor it is less effective and efficient than the firms for allocating aspirational labor.
\end{abstract}

Keywords: theory of the firm, transaction cost, knowledge, entrepreneur, aspirational community 


\section{Introduction}

The theory of the firm is important not only to economists but also to management scholars as Porter (1991: 95) points out that 'any effort to understand success must rest on an underlying theory of the firm and an associated theory of strategy'. The fundamental question that a theory of the firm must answer is the existence of the firm (Coase, 1937), namely, why, given the market and its price mechanism, does the firm come to exist? According to this criterion, there are three major theories of the firm in the extant economics and management literature, i.e., the transaction cost theory, the knowledge-based theory and the entrepreneurship theory ${ }^{\mathrm{i}}$.

These three theories offer very distinct explanations of the nature of the firm and compete for supremacy. Each of them has a particular focus on the multifaceted phenomenon of the firm, making the field fragmented without an integrated theory. The transaction cost theories focus exclusively on reducing transaction costs of searching, contracting and monitoring. The knowledge-based theories put an emphasis on pursuing synergy derived from combined resources (i.e., knowledge, competences and capabilities) that create value. The entrepreneurship theories claim that the entrepreneur and entrepreneurship have a crucial yet oft-neglected role in the formation/existence of the firm.

In the field of strategy (and more so, of economics), as Foss (1999) points out, there has been a tendency to adopt a methodologically 'isolationist' approach in conducting research in theory of the firm, namely, a methodological belief that either transaction cost logic or the knowledge-based view can develop a full-blown theory of the firm. Foss (1999: 742) argues that such an isolationist approach is problematic because the transaction cost theory and knowledge-based theory 'as they stand presently both are handicapped in some, widely different yet important, respects'. Therefore, he supports a particular integrationist approach with both methodological and substantive arguments, a research strategy that aims at combining some key ideas of the existing theories, rather than pursuing to develop a single theory, which is almost impossible because of 'the extreme complexity of the issues' involved in the phenomena of the firm.

This paper subscribes to this particular 'integrationist' approach and tries to develop a comprehensive yet integrative theory (cf. Casson, 2005). We argue such a theory is necessary and sufficient to build. It is necessary because all of the three aspects, i.e., entrepreneurship, cost reduction and value/knowledge creation, are but indispensible in the business organization we call the firm. It is sufficient because these three elements can be reconciled and combined with a conceptualization we propose of the firm as an aspirational community whose core members are the like-minded people sharing the same aspiration(s)/vision(s) ${ }^{\text {ii }}$ and in such a community the transaction costs are minimized while value/knowledge creation are maximized.

The following text is organized as follows. In section two, we review the three existing theories of the firm by explaining and critiquing their unique answers to the question of the existence of the firm. In section three, we propose an aspirational community theory of the firm (ACT) and address the three questions a traditional economic theory of the firm needs to answer, i.e., the existence, boundary and internal organization (cf. Coase, 1937) as well as the question of the competitive advantage of the firm a strategic theory of the firm needs to address (Foss, 1999). Section four concludes the paper and offers 
managerial implications of the ACT theory.

\section{The three major theories on the existence of the firm}

As Barney (1996) points out, since there has existed a widely accepted theory of the firm (i.e., the transaction cost theory) in the organizational economics, anyone who attempts to propose a new theory of the firm would not only have to explain the existence of the firm but also have to explain why such a new theory is needed. To do so necessitates analyzing the limitations and weaknesses of the existing theories. What follows in this section is a brief introduction of each of the existing three theories on the existence of the firm and a more detailed explanation of their limitations and weaknesses.

\subsection{The transaction cost theory}

Transaction cost logic: economizing on transaction costs

Before 1930s, the neoclassical 'theory of the firm' was merely a part of the wider theory of value, which was constructed 'for the purpose of assisting in the theoretical investigation of one of the central problems of economic analysis - the way in which prices and the allocation of resources among different uses are determined' (Penrose, 1959: 11). Due to such a specific purpose, the firm in the neoclassical economics is treated as an atomic entity or a 'representative firm' that behaves merely in response to the price signals. Few economists thought it necessary to enquire what happened inside the firm (Penrose, 1995: x) and the firm either remained a black box or had no 'insides'. In a sense, the neoclassical 'theory of the firm' is actually the theory of markets. Such a 'black box' treatment would ultimately invite criticisms from those who are concerned about the nature and behaviors of the real firms.

Coase (1937) was one of the first who dared to challenge the neoclassical theory of the firm and enquired into the nature of the firm. The question inspired Coase's theorization is that, if the market/price mechanism were so efficient, why did the firm come to exist at all? Coase's own answer is that, there are costs of using the market as well as the firm, i.e., costs of transacting and costs of organizing. The firm exists to reduce the transaction costs of searching and using market exchanges for everything it needs for production. However, there will also be costs of organizing the activities in the firm incurred whenever one external transaction is internalized. The firm will tend to expand its size until the increase in organizing cost is equal to or greater than the reduction of transacting cost. Regarding the issue of internal organization of the firm, Coase argues under the employment relationship, the owner of the firm has the rights to control the works of the employees by telling them when to work, what to work on and how to do it, in other words, by fiat (Williamson, 1971: 114).

In spite of the ituitive plausibility of Coase's theory, it did not make a substantial impact on the mainstream economic thinking before 1970s, which Coase lamented later that his theory was 'much cited and little used' (Coase, 1972: 68; Malmgren's (1961) theory of informational transaction cost was an exception). There are several possible reasons. One might be Coase's verbal theory could be hardly put into mathematical forms or in Williamson's (1975) term 'not been made operational', as Foss (1998: 9) points out that 'Coase had given virtually no details on the determinants of these costs'. So economists 
would not be willing or able to use it and sometime simply for the sake of publication (cf. Coase, 1988: 36). Another reason might be his theory was overshadowed by the monopolistic competition revolution in economics led by Chamberlin (1933) and Robinson (1933) and later Debreu's (1959) general equilibrium theory in his Theory of Value.

Entering into 1970s, there began to emerge some serious works on the theory of the firm. Among them is a set of important contributions to the so-called transaction cost economics (TCE), including Williamson's (1971) market failure theory of vertical integration and his $(1975,1985)$ asset specificity theory of internalization, Alchian and Demsetz's (1972) team production theory, and Jensen and Meckling' (1976) nexus of contracts theory. In late 1980s there emerged another important branch of the TCE - new property rights theory - developed by Grossman and Hart (1986) and Hart and Moore (1990). Although the TCE consists of diverse theories, it has a shared central argument that the firm exists to economize on transaction costs of various kinds, such as agency cost (Jensen and Meckling, 1976; cf. Ross, 1973), cost of shirking (Alchain and Demsetz, 1972), cost of opportunism $(1975,1985)$, and cost of underinvestment (Grossman and Hart, 1986; Hart and Moore, 1990), by means of internalization of the market, i.e., the substitution of internal organization for market exchange (Williamson, 1971: 112).

Although Coase's transaction cost logic is uncommonly insightful and can scarcely be faulted (Williamson, 1975: 4), it is not without criticisms. The common criticisms of the TCE include: the transaction cost logic is tautological (Alchain and Demset, 1972: 783; Masten, Meehan and Snyder, 1991; Williamson, 1975: 3) and only a partial explanation (Dyer, 1997; Zajac and Olsen, 1993), TCE researches rely on indirect rather than direct measuring transaction costs (Foss, 1998: 16; Masten et al., 1991: 3-4), and the TCE, especially Oliver Williamson's version, is bad for practice (Ghoshal and Moran, 1996; Hodgson, 2004; Pfeffer, 1994).

\section{Tautology in transaction cost logic}

Masten et al. (1991) have noticed that there is a tautological formulation built into the transaction cost arguments, which is labelled by Barney (2001) as 'Coasian tautology'. Namely, the central hypothesis underlying TCE is that the choice of which governance mode (i.e., market or the firm) to choose depends completely on the comparison between the costs of organizing under the corresponding alternative. However, the direct comparison is impossible for two reasons. First, such costs are difficult to observe and measure given some implicit or latent costs exist; second, the cost of organizing under the alternative mode cannot be directly observed and measured because once one mode is chosen the alternative mode is simultaneously forgone. So, Masten et al. (1991) point out that Coase's original transaction cost argument is easy to make and impossible to refute, which can 'call into questions of the entire edifice' of transaction cost theory (Ghoshal and Moran, 1996: 23).

\section{Transaction cost is a partial explanation}

Transaction cost theory, by focusing solely on cost issue, completely neglects other aspects of commercial exchange, i.e., the value side and the distribution of value created, which are two fundamental questions concerning the theory of the firm (Asher, Mahoney and Mahoney, 2005). For example, Zajac and Olsen (1993) argue that transaction cost 
perspective has at least two limitations when used to analyze interorganizational strategies: (1) a single-party, cost minimization emphasis that neglects the interdependence between exchange partners in the pursuit of joint value, and (2) an overemphasis on the structural features of interorganizational exchange that neglects important process issues. They propose instead a transactional value framework for analyzing inteorganizational strategies that emphasizes joint value maximization. Dyer (1997) echoes this view and contends that the fundamental governance question is 'how can exchange relations be structured to maximize transaction value' rather than 'to economize on transaction costs'?

\section{Indirect tests in TCE researches}

In order to sidestep the direct comparison problem, TCE scholars have adopted the indirect tests apparoach. Foss (1998: 16) notices that 'formal contributions prefer in general not to use the concept [transaction costs] at all (or only in a verbal introduction) and to model not transaction cost per se, but rather the manifestations of transaction costs'. To do so, as Masten et al. (1991: 3-4) observe, TCE scholars 'relate the incidence of transaction costs to observable characteristics of the transaction and then base predictions of organization form on those observed features', a common strategy is 'to estimate organizational form as a function of observable characteristics such as the degree of asset specificity and the level of uncertainty or complexity associated with the transaction'. Obviously, this is precisely how Williamson's theory is developed.

However, Masten et al. (1991: 4) rightly point out 'a finding that higher asset specificity leads to a larger probability of integration could, in principle, obtain even if the hypothesis that asset specificity raises contracting costs were invalid [italic added]'. And indeed, the hypothesis is invalid as Dyer (1996, 1997: 536) has shown by the evidences of Japanese automaker-supplier keiretsu that, compared with US counterparts, the Japanese transactors incurred significantly lower transaction costs even though they had made greater asset-specific investments; and more interestingly, the automaker with the least specialized supplier group (GM) had the highest transaction costs while the automaker with the most specialized supplier group (Toyota) had the lowest transaction costs.

\section{TCE is bad for practice}

The most serious attack on TCE, especially on Williamson's opportunism-based theory, is the criticism of 'bad for practice' (Ghoshal and Moran, 1996; Hodgson, 2004; Pfeffer, 1994). The critics argue Williamson's theory is established on false or biased assumptions about human nature, i.e., being opportunistic. According to psychology theories, people's attitudes and behaviors are likely to be modified in response to their perceptions how they are treated by other people surrounding them. Negative perception derived from mistrust due to the opportunism assumption may reinforce people's opportunistic attitude and behaviors through a positive feedback loop. Therefore, the opportunism becomes a selffulfilling prophecy. Due to the self-fulfilling propensity of the opportunism-based TCE theory, it is very dangerous for management practice to design organizational control and incentive mechanisms according to this theory. The irony of the opportunism-based TCE theory is that it is likely to cause more opportunistic behaviors that the theory is designed to reduce. 
In addition, Ghoshal and Moran (1996: 23) argues Williamson's logic that hierarchical control can reduce opportunistic behavior is not justifiable because the net effect of hierarchical control on opportunistic behavior will depend in part on the relative strengths of two distinct and mutually contradictory effect, i.e., formal control can in some situation constrain opportunistic behavior and in some other situation can invite opportunistic behavior due to lack of trust and negative feeling for the management, and the directionality of this net effect cannot be theoretically determined.

\section{TCE offers a suboptimal solution}

Besides these above mentioned common criticisms, we argue, the transaction cost theories as currently presented have offered suboptimal solutions to the transaction cost problem, namely, in order to avoid or minimize transaction costs the entrepreneur should internalize the external market transactions; however, we argue, internalization should be the last choice rather than the first choice to consider for such a purpose.

The most commonly conceived transaction costs include costs of searching, negotiation/contracting and monitoring/enforcement. To minimize or avoid searching and negotiation/contracting/ costs, the first choice should be to design a long-term contract rather than internalizing the established arm's length transactions. First of all, a long-term contract will reduce one's needs for frequent searching alternative suppliers otherwise. In situations where periodical searching for better suppliers is conducted alongside the longterm contract, the newly incurred searching costs can never be avoided and internalization is irrelevant. Secondly, a long-term contract will also reduce one's needs for frequent negotiation and hence contracting costs otherwise because what remains is less frequently periodical renegotiations of the contract. Thirdly, a long-term contract will be implemented as a repeated game that, according to the game theory, will automatically reduce the opportunistic behaviors and therefore the monitoring/enforcement costs.

Internalization may be a wrong choice because we can choose to 'vote with feet' rather than internalize to punish opportunistic behaviors. Apparently, internalizing or employing opportunistic people is a decisively wrong decision to make in the first place because, on the one hand the opportunistic people will behave opportunistically whenever possible, and on the other hand there are many faithful people in the market so why not searching for them? In many cases, it may be more economical to invest extra time for searching for faithful people rather than invest in monitoring the opportunistic people?

\subsection{The knowledge-based theory}

The knowledge-based logic: creating positives vs. avoiding negatives

As Coase (1988: 47) himself later recognized, while his theory 'emphasized the comparison of the costs of transacting with the cost of organizing', he 'did not investigate the factors that would make the costs of organizing lower for some firm than for others', i.e., the firm-specific factors which give one firm an competitive advantage over another firm. Evidently, this omission prevails in most of the economic researches on the firm. In response, many economists outside the mainstream economics and scholars of organization and management studies have tried to address the question of what are the sources of firm heterogeneity or competitive advantages.

In 1959, Edith Penrose published her landmark book The Theory of the Growth of the 
Firm. Although Penrose's focus was on the growth of the firm and the limits on the growth rate, she nevertheless laid down the intellectual foundation of what was later called the resource-based view of the firm (RBV) (Wernerfelt, 1984) that sees the firm as a collection of productive resources. Following Penrose, scholars have expanded the scope of the RBV to include core competence view (Prahalad and Hamel, 1990), knowledge-based view (Conner, 1991; Kogut and Zander, 1992) and dynamic capability view (Teece, Pisano, and Shuen, 1997), among others.

In an attempt to establish an alternative to the dominant transaction cost theory of the firm, Conner (1991) argues that we can treat the firm as not only an 'avoider of a negative' but also a 'creator of a positive'. Although Conner's intention was to transform the loosely defined resource-based view of the firm into an explicit resource-based theory of the firm, she has actually established a knowledge-based theory of the firm (KBT). According to Conner, the RBV implies a theory of firm existence that the firm is more advantageous than the market contract in inter-component knowledge transplantation and in the creation and redeployment of specific assets; in addition, the RBV has an implicit theory of firm boundary that turns on the firm's advantages over the market in creating and redeploying specific assets. Although Conner mainly attended to the existence and boundary issues, she also offered an implicit theory of the competitive advantage of the firm that associates the firm's competitive advantage to the strength of firm-level linkages such as corporate culture and routines.

About the same time, independent of Conner's (1991) paper, Kogut and Zander (1992) published their own knowledge-based theory of the firm. Kogut and Zander (1992, 1993, 1996) argue that the firm comes to exist because it is a more effective mechanism and a social community with organizing principle for knowledge transfering and generation due to the tacitness of much human knowledge and the shared organizational identity. Following Kogut and Zander, many other scholars have enriched the knowledge-based theory (e.g., Conner and Prahalad, 1996; Grant, 1996a, 1996b; Madhok, 1996; Nahapiet and Ghoshal, 1998; Nickerson and Zenger, 2004).

As intentionally proposed as a 'positive' alternative to the 'negative' transaction cost theory for explaining the existence of the firm, the knowledge-based theory as currently presented, though being intuitively plausible (Håkanson, 2010), also suffer from several limitations and weaknesses, i.e., the conceptual ambiguities, the lack of robustness and a doubtful assumption.

\section{The conceptual ambiguities in KBT}

As Håkanson (2010) points out, there are four ambiguities in the diverse conceptualizations of knowledge. The first ambiguity is a definitional one as there has been a lack of agreement as to the definition of the central concept of knowledge (also of competence and capability). The second one concerns the relevant level of analysis (Felin and Foss, 2005; Felin and Hesterly, 2007), i.e., whether knowledge resides in individuals or in organizational collectivity. The third ambiguity arises due to the use of highly abstract versus more elaborate classifications of knowledge. The fourth one relates to the treatment whether knowledge is stable or dynamic. Due to these conceptual ambiguities, it is not surprising that Kaplan et al. (2001: 3) contend that 'the knowledge-based theory of the firm seems like a theoretical patchwork than a solid body of theoretical knowledge'. 


\section{The KBT's lack of robustness}

Williamson (1999: 1094) and Winter (1995: 149) criticize the knowledge-based perspective has an expansion tendency, namely, its theorists tend to commoditize the concept of knowledge, capability, resource and routine, etc. to include so many different things, which in turn make it almost impossible to 'breathe operational content into such competence features' which is, to Williamson (1999: 1097), a need for those competence perspective holders. In addition, when comparing the governance/contractual perspective and the competence perspective, Williamson (1999) critiques the core competence theory as lacking of apparatus therefore the theory can only offer 'ex post rationalization', namely, the core competence theorists tend to say, "show me a success story, we will identify a core competence; or show me a failure story, we will specify a missing competence".

Foss (1998: 19) points out a problem in the knowledge-based theories. Namely, all incentive conflict problems are suppressed in order to focus on the costs of storing, using, producing and transmitting information and knowledge. This is very unrealistic given the undisputable existence of conflict of interests in our economies and societies. Also, Foss argues that the competence perspective has largely originated in the outskirts of economics such as business strategy, international business, technology studies, etc., and therefore is considerably looser than most mainstream economic theories of the firm. If they are best for explaining the competitive advantage of the firm, they are not robust to deal with the existence and boundary issues although most of the knowledge-based theorists often strive to address those issues.

\section{A doubtful assumption of the KBT}

The KBT has an implicit assumption that putting people together (e.g., in a firm) will automatically generate knowledge (and more effectively than the market can). Conner (1991: 140) actually explicitly asserts that 'gains from in-house activity are likely to arise whether or not there is a conscious [italic in orginal]...Rather, the existence of gains is likely to result automatically from the underlying linkedness [italic in orginal] of the firm's resources and resource conversion activities'. This assumption is doubtful because it neglects people's willingness and commitment as the motivational precondition for knowledge sharing and creation. A mere change from market transaction relationship to a firm employment relationship does not automatically induce the employed people to be willing and committed to share their knowledge (tacit or not) with their fellow employees.

To address the motivational issue, Kogut and Zander (1996) argue that the firm as a social community creates a sense of shared identity that induces knowledge sharing and learning among its employees. Although this can be seen as an advancement in the knowledge-based line of reasoning, it still falls short of an ultimate answer because having an shared identity of being an employee of a firm does not automatically motivate a person to be willing and committed to share and create knowledge. For instance, in the traditional Chinese practice of apprenticeship, it was often the case that the masters often did not teach/transfer their entire knowledge to their disciples but instead held some secret parts in order to make themselves superior to their disciples, sometimes even until their deaths. Therefore, in the knowledge-based logic, there has been a missing link between an employee's identity of being a part of the firm and his willngness and 
commitment to knowledge sharing and creation.

Håkanson (2010) proposes a solution to this problem by conceptualizing the firm as an epistemic community that provides superior enabling and motivational conditions for the combination and integration of tacit functional or occupational expertise. He further argues that 'the establishment of a firm as [italic added] an epistemic community requires transaction-specific investments on part both of the owners, managers, and employees which is why these conditions are difficult to create under market and other non-firm modes of governance'. This is an interesting argument; however, Håkanson's theory has two weaknesses. On the one hand, being a part of an epistemic community does not automatically guarantee that one will be willing and committed to share and create knowledge. On the other hand, it is doubtful whether the purpose or direction of a firm is to establish it into an epistemic community in which members of the community have a similar or same cognitive/epistemic background and often possess the same tacit and experiential knowledge. In theory, many scholars have argued (for a review, see Jackson, Joshi and Erhardt (2003)) that a firm should strive for diversity in its human resource management in terms of the employees' backgrounds and expertises. In practice, many firms do pursue such a diversity in their recruitment practices. More seriously, pursuing a firm as a homogeneous epistemic community may invite cognitive rigidity and even the 'not invented here' (NIH) syndrome (cf. Katz and Allen, 1982).

\subsection{The entrepreneurship theory}

Casson $(2000,2005)$ argues that existing theories of the firm are partial theories because they have largely neglected the entrepreneurial dimension of the firm. Casson (2005) offers two possible reasons for the neglect of entrepreneurship by theorists of the firm. One is that, the traditional literature on entrepreneurship, such as Cantillon (1755) and Knight (1921), is economic and has little relevance to management of the firm. The other reason is that, some of the economic literature on entrepreneurship involves distinctive psychological assumptions which though very insightful do not fit with mainstream theory. In addition, Foss and Klein (2005) find another reason, namely, many recent theories of entrepreneurship, such as entrepreneurship as imagination or creativity, entrepreneurship as innovation, entrepreneurship as alertness or discovery, and entrepreneurship as charismatic leadership, do not provide a natural links to the theory of the firm.

On the other hand, Witt (1999) points out that 'theories focusing on the entrepreneurial element in the economy, in particular the contributions in the Austrian tradition, have paid hardly any attention to the role of the firm'. Therefore, there has been a missing chapter on the role of the firm in Austrian economics. Many people have made substantial efforts in bridging the theory of entrepreneurship and the theory of the firm, resulting in an emerging entrepreneurial approach to the theory of the firm (e.g., Alvarez and Barney, 2004; Casson, 2000, 2005; Dew, Velamuri and Venkataraman, 2004; Foss, 1994, 1997; Foss and Klein, 2005; Foss, Foss, and Klein, 2007; Langlois, 1988; Silver, 1984; Witt, 1999, 2001).

The dominant logic in the entrepreneurial approach is that, it is a special type of market failure, i.e., the absence of a market for the entrepreneur's services (Foss, 1993: 136), that calls for the formation of a firm by the entrepreneur. In other words, 'if the entrepreneur 
could sell the opportunity she has recognized at a price that satisfies her, then we would say that a market exists for the opportunity. It is because no such market exists that she has to hire herself by starting a firm' (Dew, Velamuri and Venkataraman, 2004: 669). The answer to the question why there is no such a market for entrepreneurial services given by Fose (1993: 136) is that 'there does not in the market exist a way to evaluate the entrepreneur's worth on the basis of his marginal productivty' as Kirzner (1979: 181) contends that 'entrepreneurship reveals to the market what the market did not realize was available, or indeed, needed at all'. Foss and Klein (2005) adopt Catillon's (1755) conceptualization of entrepreneurship as judgmental decision making under the condition of uncertainty. Under uncertainty, the other market participants may be unable to either accept or understand the entrepreneur's subjectively perceived means-ends framework, which to his or her mind spells out the preferred or 'best way' of implementing the entrepreneurial idea in the marketplace (I. Zander, 2007: 1142).

Casson (2005) claims that 'the addition of entrepreneurship is not a minor refinement of the theory of the firm, but represents a radical change' while Langlois (2005) contends 'entrepreneurship, properly understood, is a crucial but neglected element in explaining the nature and boundaries of the firm'. However, we argue, the entrepreneurship theory of the firm as currently presented has misunderstood rather than properly understood the linkage between entrepreneurship and the existence of the firm.

Our critique of the market failure logic, i.e., there being no market for entrepreneurial opportunities, is simple, namely, why should an entrepreneur want to sell his entrepreneurial idea or opportunity to others in the first place? According to Venkataraman (1997), entrepreneurship is 'the process by which opportunities for the creation of markets for new products and services are recognized, pursued, and exploited' (cited in Dew et al., 2004: 662). This definition implies that a true entrepreneur will pursue the entrepreneurial ideas/opportunities once he recognized. The corollary is that if one sells his entrepreneurial ideas/opportunities to others for cash, he is not an entrepreneur by definition.

Another way of explain why an entrepreneur will not try to sell his entrepreneurial idea is as follows. Even if we assume that the entrepreneur does consider selling his idea, he will soon realize he shall not do so, because, even if we assume there is a market or someone who is interested in his idea, in order to receive a satisfactory pay for his idea, the entrepreneur has to explain every detail of his idea, e.g., what techniques are involved, what materials to buy, and how to make the product, or in short how to make money out of it; if the entrepreneur is not to explain all the details the buyers may not be convinced that the idea is worthy; however, once the entrepreneur has explained all the details the buyer may not want to pay because he can just walk away and start the business without really 'buying' the idea he already knew. Today there is sophisticated market for technology, however, long time ago when the first ever entrepreneurial firm was about to start, such institutions preventing stealing other people's intellectual properties, e.g., an entrepreneurial idea, were not there. So, entrepreneurs would not take such risks to try to explain their entrepreneurial ideas to others.

Foss (1993: 136, in footnote 12) ironically claims that there is an affinity of his reasoning of 'absence of market for entrepreneurial services' to Schumpeter's (1934: 89) conceptualization of entrepreneurship that asserts the entrepreneur carries out 
entrepreneurial activities not by convincing people the desirability of his plan but by buying them or their services and using them as he sees fit. Schumpeter's theory implies that the entrepreneur will never consider selling his entrepreneurial idea/plan on the market regardless of whether there is such a market or not. In Casson's (1982: 14) words, 'the entrepreneur believes he is right, while everyone else is wrong. Thus the essence of entrepreneurship is being different', which is a Schumpeterian position. Obviously, when an entrepreneur gets an entrepreneurial idea, he will not consider selling it to the market regardless of the existence of such a market, simply because, for one, if he does consider selling the idea, he is not different from other ordinary non-entrepreneurs; for another, without an entrepreneurial/innovative idea, he could not make his business different from others.

\section{Toward an integrative theory of the firm 3.1 The need for an integrative theory}

From above analyses we can see that, all the three theories as currently presented have some limitations and weaknesses in explaining the fundamental question of the existence of the firm, due to which, none of these theories alone offers a satisfactory analysis. For instance, both the TCE and the entrepreneurship perspective are 'single-party' focused analyses that neglect the interdependence between exchange partners (cf. Zajac and Olsen, 1993).

Take the TCE first. Williamson (1975) places heave emphasis on bounded rationality paired with uncertainty on the one hand and small numbers joined by opportunism on the other to explain why internal organization arises to substitute market transactions. Williamson's analysis is single-party focused because it is the entrepreneur/firm in question that unilaterally wants to internalize the other party of the transactional relationship due to his bounded rationality and perception of other party's opportunism. In other words, what give rise to the internalization needs is the entrepreneur/firm's desire to avoid negative consequences that may result from the other party's opportunistic behaviors that the entrepreneur cannot predict ex ante due to his bounded rationality.

Likewise, Foss, Foss and Klein (2007) propose an entrepreneurial theory of the firm that implies the entrepreneur needs a firm because he can then delegate entrepreneurial judgmental decision making to his employees due to his bounded rationality, as they argue that 'such employees are expected not to carry out routine instructions in a mechanical, passive way, but to apply their own judgment to new circumstances or situations that may be unknown [italic added] to the employer'.

The problem of such a single-party-focused analysis is that, even if we accept the importance of the enterpreneur's desire to avoid negative by internalizing the other party of the market exchange relationship, we still wonder why the other party will be willing to be internalized or employed by the entrepreneur/firm if the only purpose of this internalization/employment is to help the entrepreneur/firm to avoid negative consequences due to his uncertainty or perception of other people's opportunism? What is missing here, and quite importantly, is an analysis of the benefit of such a relationship change to the party that is to be internalized. Although the KBT is by design two-parties focused, i.e., being concerned about joint value/knowledge generation which establishes such a benefit for both parties, the KBT nevertheless has not offered a satisfactory 
analysis why putting resources/people together will automatically result in synergy effect; put simply, there is a missing component of motivational factor in the knowledge-based perspective.

The limitations of the three theories aside, they all have offered some unique insights about the different aspects of the firm, i.e., entrepreneurship, cost reduction and value/knowledge creation, which are complementary rather than substitutive to eather other. In addition, newly proposed perspectives do not exclude the earlier ones. For example, the KBT does not reject the TCE logic (Conner, 1991) while the entrepreneurship theory was initially proposed as an extension of the KBT (Foss, 1993: 135). Therefore, it is not only necessary but also sufficient to develop an integrative theory of the firm in a particular way that combines some insights of the three theories. In this section, we propose such a candidate theory with a conceptualization of the firm as an aspirational community.

\subsection{The firm as an aspirational community}

Inspired by Alchain and Demsetz (1972), Jensen and Meckling (1976) propose the 'nexus of contracts' conceptualization of the firm, which views the firm 'as a team whose members act from self-interest but realize that their destinies depend to some extent on the survival of the team in its competition with other teams' (Fama, 1980: 289). Except profit maximization, the firm as a 'legal fiction' (Jensen and Meckling, 1976) has no other social purpose (cf. Friedman, 1970). In contrast, Kogut and Zander (1996) view the firm as a social community with a social function of association because people long to belong. Such a social community view is also implicitly supported by Alchain and Demsetz (1972) who argue that 'every team member would prefer a team in which no one, not even himself, shirked'.

Building on such a social community view, we go one step further to conceptualize the firm as an aspirational community whose members share the same or some part of the aspiration(s) of the organization (initially, of the founder(s)). Such an aspirational community can be divided into three parts, i.e., the core, the semi-core, and the periphery (see Figure 1).

The members of the core are those who strongly share the same or most of the firm's aspirations and therefore are the most stable and loyal members of the community. The core members are normally the cofounders and the early followers who shared the founders' aspirations but did not invest initial capital for some reasons but latter were rewarded the firm's stocks. The core members act for shared interests and would be willing and ready to make self-sacrifices for the shared interests. This can explain some political organizations in which the early members are often willing to make selfsacrifices in pursuit the shared goal/aspiration, even with their lives. The members of the periphery are those who share least of the firm's aspirations. It is likely that many of the periphery members join the firm not because of the firm's aspirations but due to job reasons or simply because they have not found a preferred alternative place to work and they may leave the firm whenever a more attractive job offer is available. The semi-core consists of those people who can be classified as staying in between the core and the periphery of the community because they are more stable and loyal than the periphery employees while less stable and loyal than those core members. 
Figure 1: The firm as an aspirational community

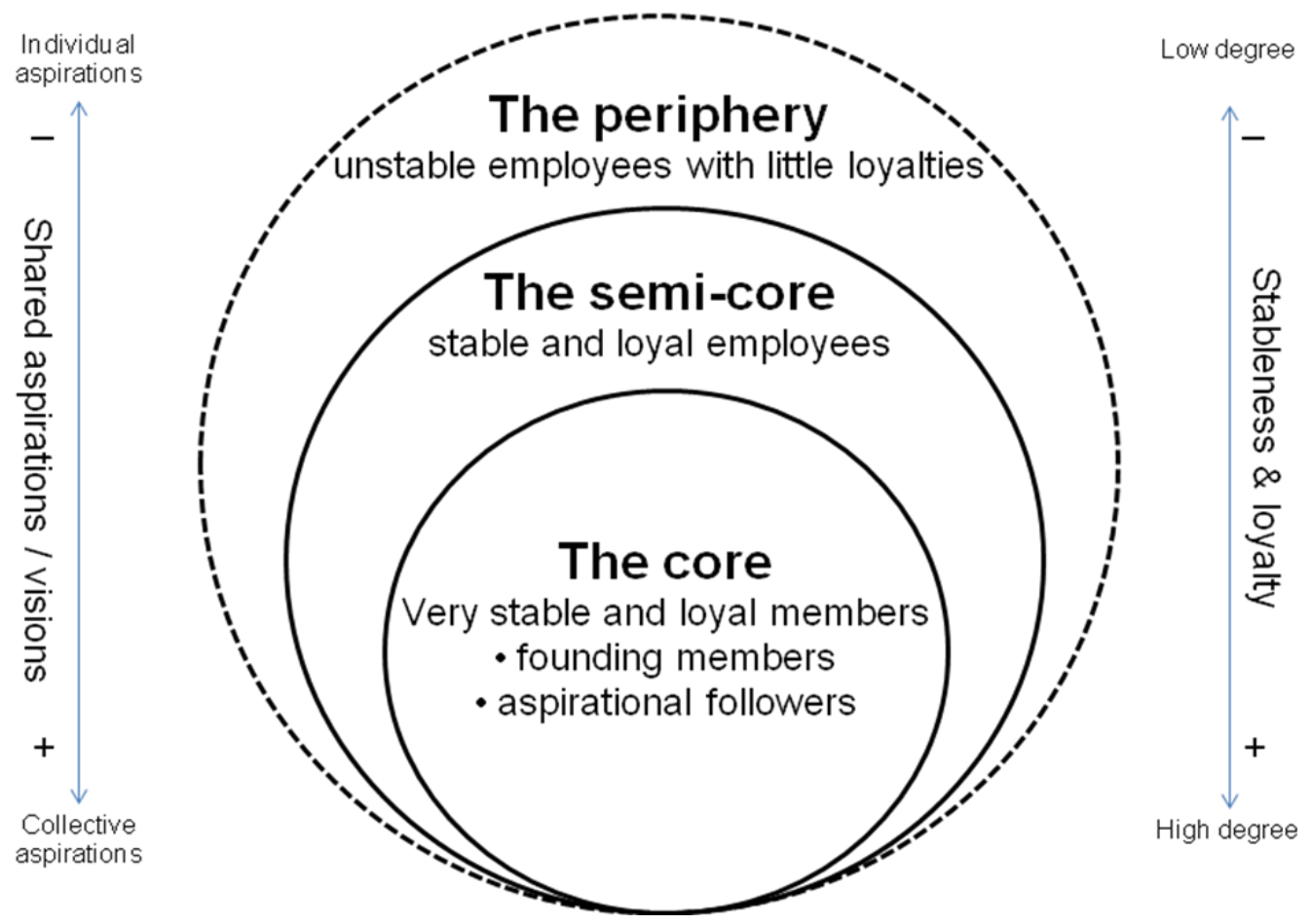

\subsection{The existence of the firm}

Our aspirational community theory of the firm (ACT) offers an alternative explanation of the existence of the firm that combines entrepreneurship, transaction costs and knowledge generation logics.

\section{Entrepreneurship under uncertainty}

Uncertainty is a key concept used in transaction cost economics and the entrepreneurship approach to the theory of the firm. According to Williamson (1975: 9), 'the pairing of uncertainty with bounded rationality and the joining of small numbers with what I shall refer to as opportunism' can explain the need for substitution of internal organization for the market transactions. Foss and Klein (2005) adopt the conceptualization of entrepreneurship as judgmental decision making under uncertainty. Scholars have identified all sorts of uncertainty in entrepreneurship, for example, Malmgren (1961) focuses on the informational uncertainty about the production and price while Foss et al. (2007) see the ex ante unknown optimal relationships among heterogeneous resources as one type of uncertainty. In a sense, uncertainty has been framed as a perception of unpredictability of the external environment (cf. Williamson, 1975: 9). Although such uncertainties about the changes of the environmental factors are real ones, we submit that the most fundamental uncertainty the entrepreneur faces before and in the early stage of carrying out his entrepreneurial plan is that, he is uncertain about whether his entrepreneurial business will succeed and often time he is even uncertain about whether it can survive tomorrow.

With the uncertainty perceiption, the entrepreneur may have two distinct attitudes 
towards working with others, depending on his relationship orientation or regulatory focus (Higgins, 1998; Weber, Mayer and Macher, 2011). Namely, if he is pessimistic about the working relationships with the other people, for example, suspecting the others may be opportunistic, he tends to adopt a prevent strategy to avoid negative consequences; in contrast, if he is optimistic, he may see working with others as opportunities, and therefore he tend to adopt a promotion strategy to create positive outcomes. When it comes to the formation of the firm, there is no way for us to ascertain whether the first ever entrepreneur (or entrepreneurs in general) was pessimistic or optimistic, and therefore, we can only argue that both situations are equally possible. We will elaborate the different possibilities in the following paragraphs.

Given above analysis, we propose an integrative entrepreneurial model of the formation of the firm, which well reconciles the competition between the transaction cost and the knowledge-based perspectives (see Figure 2). In our view, the formation of the firm normally starts with an entrepreneurial idea or opportunity recognized by an entrepreneur; however, due to his uncertainty perception coupled with his regulatory focus, he will have a specific attitude towards working with other people (relationship orientation), i.e., either pessimistic (prevention-type) or optimistic (promotion-type) or a mix of the two. Due to his relationship orientation, he may adopt a strategy of either avoiding negatives or creating positives or a mix of the two accordingly; and once he has made up his mind and taken actions, the firm is then formed.

Figure 2: An integrative entrepreneurial model of the formation of the firm

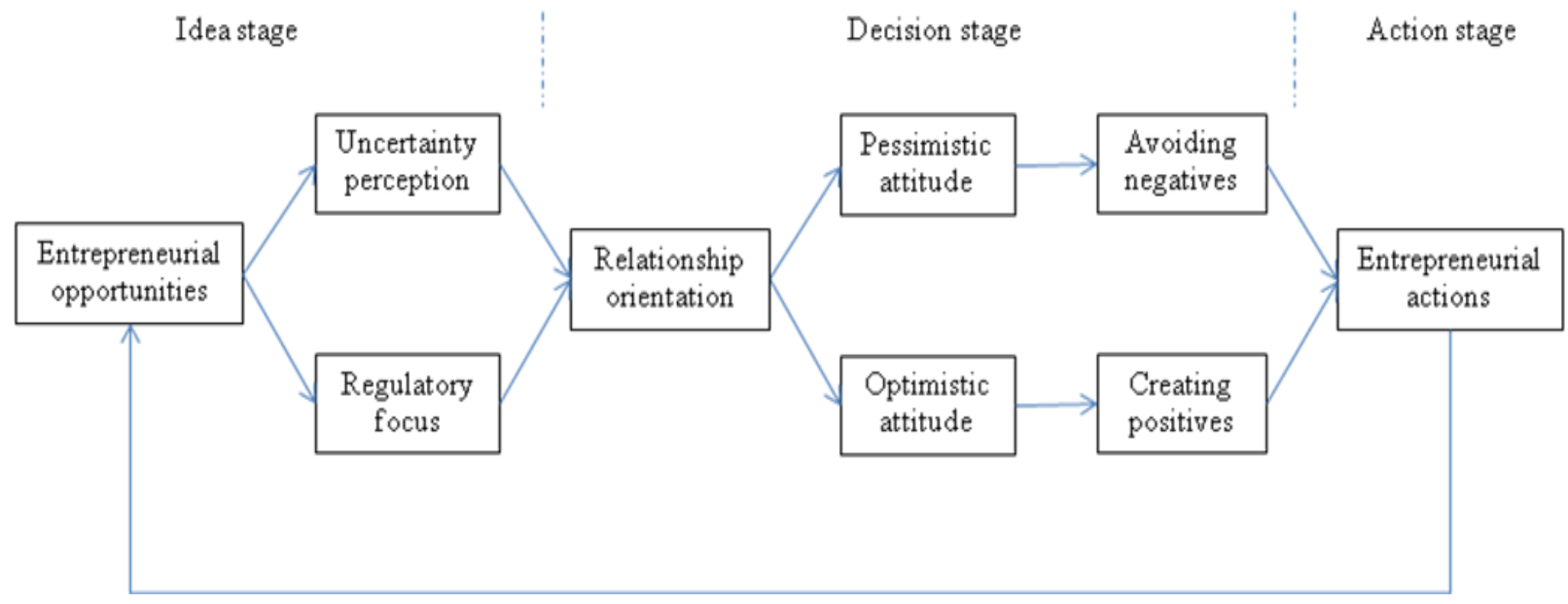

It is worth noting that there might be another possibility that the first ever firm was not initiated by an entrepreneur but a result of his response to some non-entrepreneurs who asked or invited the entrepreneur to start a firm with a consideration of the collective action problem that without a risk-taking uncertainty-tolerant entrepreneur none of these non-entrepreneurs would not assume such a leadership position.

\section{Avoidance of transaction costs}

Under such uncertainty, it is troublesome and expensive to use the market for getting the labor and capital the entrepreneur needs in order to run his business. It is troublesome because the suppliers of labor and capital may be impatient and will frequently ask for 
payments for their supplies. It is expensive because the entrepreneur has to divert his time and energy to deal with these payment issues frequently. Such a diversion of the entreprenur's time and energy is costly because the survival of the new venture in its early stage of development often hinges on the performance of the entrepreneur. The diversion of the precious time and energy of the entrepreneur, especially during the early stage of the development of the entrepreneurial firm, can be viewed as a special type of transaction costs for using the market.

However, the solution to this transaction costs problem is not one of simple internalization as argued by Coase (1937), because those impatient suppliers of labor after employed by the entrepreneur will still bother the entrepreneur with payment issues whenever they see a sign of financial difficulty in the entrepreneurial business. Instead, the ACT's solution for the entrepreneur to deal with this problem is to seek cheap supplies of labor and capital. In terms of cheap supply of capital, the first choice is capital gathered within his family or borrowed from his close friends; the second choice is capital gathered from some like-minded people who share the same entrepreneurial aspiration(s); the third best choice is the venture capital while the last one is the bank loans. In terms of cheap supply of labor, the first choice is family members; the second is the like-minded people who share the same entrepreneurial aspiration(s), no matter if they will invest initial capital into the business or not; and the third choice is hiring ordinary employees from the market.

By attracting like-minded people sharing the same aspirations and establish the firm as an aspirational community, the entrepreneur can not only avoid such a diversion-type transaction costs, but also reduce the traditional transaction costs of negotiating and monitoring with these group of people. These people sharing the same aspirations join the firm in its early stage of development will be the core members of the aspirational community as described above. Due to their shared aspiration and shared interests, the core members (especially the cofounders) may make self-sacrifices in order to pursue their shared interests. Before the entrepreneurial business makes a profit, the core members work together almost like for free, which can be seen as a different types of reduction of transaction costs.

\section{Value/knowledge generation}

When it comes to value/knowledge generation, the KBT has not had a satisfactory analysis of the motivation for knowledge sharing and generation. The ACT identifies two such motivational factors that determine the aspirational firm will be more efficient than the market in facilitating knowledge generation. The first is an interpersonal one, namely, within an aspirational community/firm, due to the shared aspirations/goals and the shared interests, the core members will be willing and committed to share knowledge with each other, which is important for knowledge generation. The second is a personal motivation that a person working with an aspiration will tend to be more productive and creative. To better explain this, here we make a distinction between contractual labor and aspirational labor, the former being defined as services provided by a laborer in fulfillment of a contract while the latter as services provided by a laborer in pursuit of an aspiration. The argument we make here is that, for the same person, the performance of his aspirational labor is in general higher than that of his contractual labor. We explain as follows why this is so. 
According to Hart and Moore (2008) (based on Williamson's (1975: 266) terminology), a laborer can have two types of performance when using his labor, perfunctory and consummate performances. Perfunctory performance is the basic performance 'within the letter of the contract' while the consummate performance is the exemplary performance 'within the spirit of the contract'. Because each party of a market contractual relationship has the discretion to provide perfunctory or consummate performance depends on how well one party is treated by the other. Due to the assumption that only perfunctory performance is enforceable while consummate performance is always discretionary (Hart, 2008: 407) and the hedonic principle that people in general approach pleasure and avoid pain (Higgins, 1998), we can argue that, in a market-based contractual relationship, the two parties involved tend to deliver perfunctory rather than consummate performances. There are two reasons why this is so. On the one hand, the buying party (or buyer) will pay the agreed price for the product or service provided by the selling party (or seller) if the quality of the product and service reaches an acceptable (i.e., perfunctory) level and normally due to self-interest pursuing tendency the buyer will not pay (or will not fully pay) the extra if the quality of the product and service is higher than the minimally acceptable level (e.g., consummate level). In the latter situation the buyer will gain buyer's surplus derived from the difference between the accepted quality and the minimally acceptable quality (or what he paid). On the other hand, knowing that the buyer would normally not pay or not fully pay for the difference between a consummate performance and the minimally acceptable (i.e., perfunctory) performance, the seller would tend to deliver perfunctory rather than consummate labor service (or product) because to achieve consummate performance demands investing extra time and energy on the part of the task performer who is uncertain if his consummate performance will be paid for or fully paid for.

Another reason why the market-based exchange can hardly induce consummate labor services is because of the psychological impact of market-based contracts that are commonly prevention-framed. According to Weber and Mayer (2011), a prevention frame leads to an interpretation of a goal as a minimally acceptable level of performance (something that must be met otherwise it would be unacceptable), which induces highintensity negative emotions if the goal is not achieved and low-intensity positive emotions if the goal is met. This implies that the buyer would tend to not pay for the extra level of quality and the seller would not tend to provide such extra due to the lowintensity of positive emotions. In sharp contrast, a promotion frame leads to an interpretation of a goal as a maximal ideal result, which induces low-intensity negative emotions if the goal is missed and high-intensity positive emotions if an ideal result is reached. Therefore, while the prevention frame contracts invite perfunctory performances the promotion frame foster flexible and creative behaviors.

From Figure 3 we can see, there are different levels of labor performance associated with different modes of exchange relationships due to the degree of shared interests built into the exchange relationships. Firstly, arm's length market-based exchanges are normally based on prevention frame contracts because of the lowest degree of shared interests, which result in contractual labor with perfunctory performances. Secondly, with more shared interests between alliance partners, the alliance contracts often involve prevention as well as promotion frame clauses; due to the promotion frame elements the labor performances tend to be higher than those of the arm's length exchange contracts. Thirdly, 
for those employees of the firm's periphery, their labor services are still normally of contractual nature (with promotion as well as prevention clauses); however, they may occasionally pursue consummate performance with extrinsic motivations, i.e., performance-based bonus. Fourthly, for the firm's semi-core employees, they may provide aspirational labor on top of his contractual labor because they do share more of the firm's aspirations than the periphery employees do; in addition, they may pursue consummate performance with intrinsic motivations, i.e., career consideration or merely feeling good by doing well. Lastly, for the firm's core members, their labor services are first of all of aspirational nature while there are also contractual elements involved; however, when it comes to their contractual labor services, they will pursue consummate performance within intrinsic motivation because of their strong shared aspirations as well as the high degree of shared interests.

\section{Figure 3: The allocation of contractual and aspirational labor}

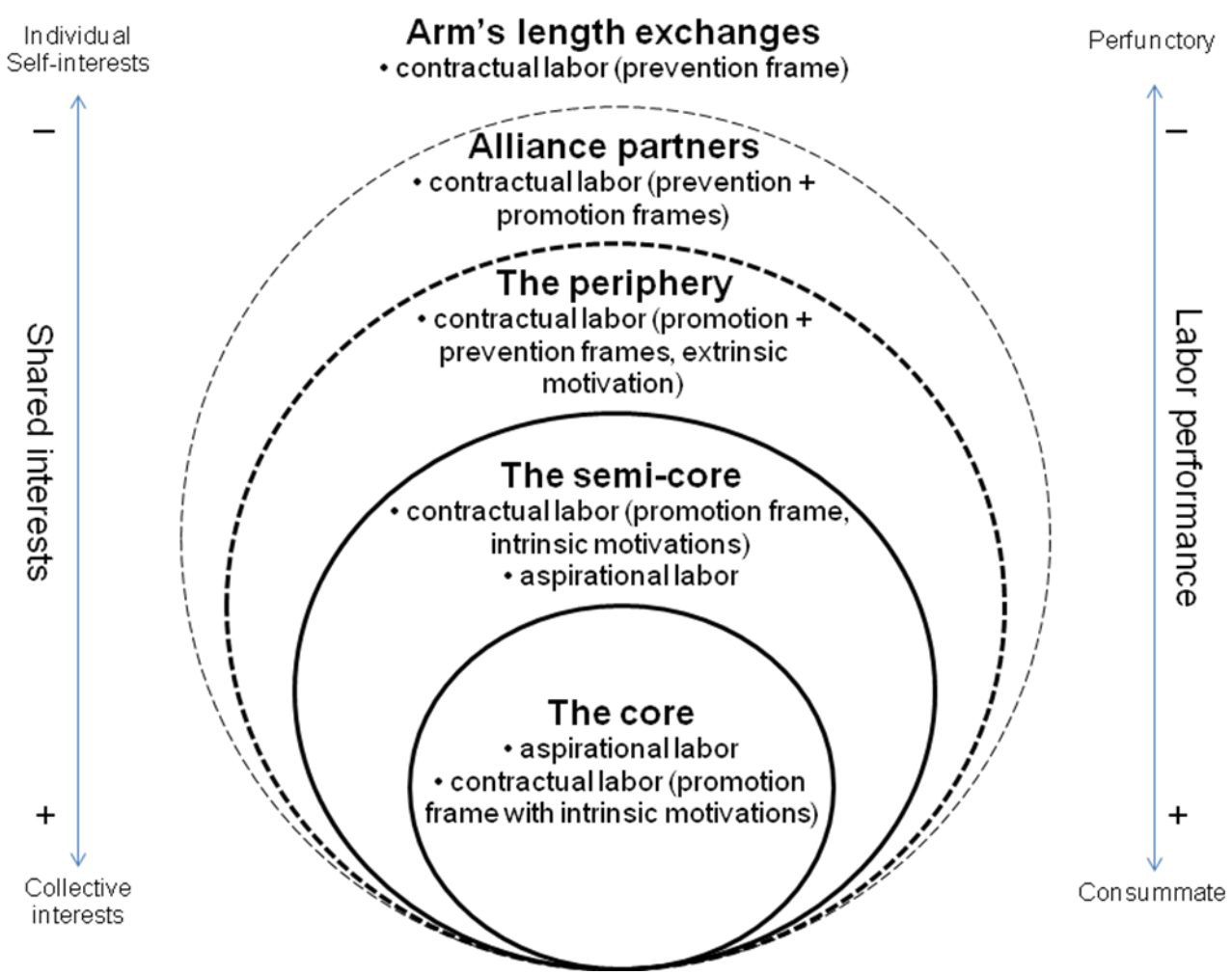

From above analysis we can see that, the firm is more effective than the market for inducing consummate performance of labor (including knowledge labor), which explains why the firm is better than the market in value/knowledge generation. Clearly, the performance difference is due to alignment of interests between exchange parties that the firm as an aspirational community has competitive advantage over the market in this respect.

\subsection{The boundary of the firm}

Organization forms: market, hierarchy and alliance 
The boundary of the firm is initially defined as a 'buy or make' question, namely, whether an industrial activity should be organized by the market or within the firm. Although the existing literature offers many insights in addressing this question, Richardson (1972) points out that the sharp dichotomy between firm and market is misleading because in between these two extreme organization forms of industrial activities there are intermediate areas where inter-firm cooperation and affiliation may take. The inter-firm relationship within such intermediate areas can take different forms such as long-term contracts, joint ventures, franchising, strategic alliance, and networks. All of these organizational forms can be called as alliances which are hybrids of market and hierarchy, in which complex networks of cooperation and association exist. Therefore, rather than making a dualism of either market or the firm, we argue there are three broad categories of organizational forms, i.e., market, alliance, and hierarchy.

The hierarchy and alliance can be grouped together as non-market organization forms of industrial activities. What distinguishes between the market and non-market forms is whether the exchange partners involved have some shared interests or not. In the purely market-based exchange case, the parties involved have no shared interests and they fulfill the contracts based on purely maximize their self-interests. In contrast, in the inter-firm alliance case, although the alliance partners will still prioritize their self-interests, there will be overlaps of interests because all parties are aware that their individual success will depend on the overall success of the alliance. Such a sense of interdependence will be even stronger for the firm employees, even for the peripheral employees. On the other hand, as we acknowledge, the peripheral employees share little of the firm's aspirations and may leave the firm whenever more attractive job offers are available, we can see that the boundary of the firm becomes blurred because, on the one hand, the relationship between the firm and its peripheral employees is not fundamentally different from those between the firm and its alliance partners; and on the other, some alliance partners may have better and more stable relationships with the firm than the peripheral employees do.

In our view, we can either treat some alliance partners as members of the firm's extended aspirational community because the firm and its alliance partners sometimes do share some aspirations (e.g., co-development of a new technology), or see the firm's periphery members as the firm's internal alliance partners (in relation to the firm's external interfirm alliance partners) because the primary connections between the firm and its alliance partners are temporary interdependence of interests. The question is when and why an external alliance partner relationship be changed to internal alliance partner relationship, which becomes a 'buy or have' question. We argue there is one extra factor to consider, besides what the traditional 'buy or make' theories suggest, that the firm should try to have an understanding as accurate as possible whether the external partner (an individual or a firm) in question shares some aspirations of the firm. If so, the internalization choice is advisable because when they work together within an aspirational community there will be benefits gained from the change from perfunctory labor to aspirational labor. Otherwise, the internalization does not make much difference. What should be avoided is to internalize/employ opportunistic people because they will behave opportunistically whenever possible no matter what monitoring mechanisms installed.

\section{The limit to the growth of the firm}

The issue of the growth of the firm is an important aspect of the nature of the firm so that 
Penrose (1959) devoted the entire book to address it. We argue that the growth of the firm depends on how attractive the firm is in relation to other firms on the one hand and how capable the firm is to retain people on the other. A firm's attractiveness derives from its aspirations as well as its economic prospects. Two types of people may be attracted to join a firm, one being those who share the same or some parts of the aspirations of the firm, and the other those who see the economic prospects of the firm are better than other firms'. A firm's capability to retain talented people depends on its capacity to transform the firm's peripherial employees into semi-core employees as well as to transform its semi-core employees into core employees. If the firm is lack of transformation capacity then the periphery employees may and will ultimately leave the firm and the semi-core employees may become periphery employees, and even some core employees may become semi-core and even periphery employees.

No matter how attractive the firm might be, it will not grow indefinitely. Penrose (1959) offers one plausible reason why this is so. Here, we provide another perspective on the limit of the firm's growth. When the firm is established with the entrepreneur's initial aspirations, people are attracted by the aspirations to join the firm. However, when they join the firm, they may not share all of the firm's aspirations, in other words, they may have suppressed some of their individual aspirations in order to pursue the firm's collective aspirations. With the growth/evolution of the firm, the firm's initial aspirations may evolve too. So, at some points in time, the firm may lose its aspirations, or its aspirations may not be strong enough to hold all of the employees together, or some employees may no longer want to suppress their individual aspirations, then some employees may leave the firm even though at the same time other new people may join the firm for various reasons. This means, it is unlikely that a firm can have some aspirations that will be attractive forever for everyone in the firm, and therefore, the firm cannot and will not grow indefinitely.

\subsection{The internal organization of the firm}

When talking about the internal organization of the firm, Coase (1937) actually only refers to the fiat-type authority of the firm/entrepreneur over the employees. Here, we will first take on the organizational authority issue and then talk about the transformation mechanism of the firm.

\section{Organizational authority}

The ACT offers an alternative viewpoint on organizational authority of the firm. Rather than lean towards either Coasian fiat-type authority or Alchian and Demsetz's (1972) view of the firm having no authority at all, the ACT maintains that the owners or their representatives (i.e., managers) do have certain authorities over their employees or subordinates. But such authority has its limit. According to Simon (1951, 1995), the employer's authority over its employees is restricted to the 'zones of acceptance' of the employees under the assumption of utility maximization rather than the neoclassical assumption of profit maximization (Simon, 1995: 279) where 'profit [consideration] is only one among a number of [considerations] and enters into most subsystems [of the firm] only in indirect ways' (Simon, 1964: 21). And the real authority lies in the capacity of the employer, under the precondition of acceptable-quality relationship, to prioritize its organizational goals over the individual goals of its employees. 
This prioritization-capacity-based authority indicates that if the employer abuses its bargaining power or if its fiat falls outside the employees' 'zones of acceptance', the employees may choose to leave the firm, and then there will be no any authority over the employees-to-leave any more. But, if the employer firstly build and harmonize its relationships with its employees, then the employer can more easily prioritize its organizational goal over employees' because the employees enjoying harmonious relationships with the employer tend to accept the prioritization and authority.

The ACT also does not prefer the formal control argued for by TCE scholars, especially by Oliver Williamson, for two reasons. First, for knowledge workers, fiat-type authority and formal control mechanisms tend to have less effects than empowerment and informal control mechanisms. Secondly, in China where relationships and harmony are highly appreciated and cultivated, the management philosophy goes that it is not impossible to achieve a perfect type of control: governing without intervening, which can be understood as the principle of subsidarity, namely, don't interfere your subordinates, if you selected them, trust them, empower them, and encourage their creativity; and then they might get tasks done effectively, efficiently and creatively. If leaders at every level in the firm follow this 'governing without interfering' principle to manage their subordinates who manage their own tasks, then the whole company can be governed without interference. It may be argued that such a 'governance without interference' situation is hardly seen in practice. However, what the ACT can shed light on this issue is that, if the firm is lead by a clear aspiration and made of like-minded people sharing such an aspiration, the more this is true, the more such a 'governing without governance' outcome will be likely to achieve.

\section{Transformation mechanism}

The demarcation of the core, the semi-core and the periphery is not static and the their boundaries can and may evolve. The core is the most important part of the firm because of the loyalties and stableness of its members. However, we should not taken that loyality and stableness for granted because the core members may also change their attitudes and behaviors if they are not well treated.

The firm should strive for transforming the semi-core members into the core members because, on the one hand, it is much easier for the firm to transform the semi-core members into core members than to transform the periphery members into semi-core members because the semi-core members share much more of the firm's aspirations than the periphery members do, and on the other, the semi-core members can be turned into the periphery members depending on how well they are treated within the community.

For the periphery members, the firm needs a cost-benefit analysis to decide if it should strive for transforming the periphery members into semi-periphery members because to pursue such a transformation the firm has to invest heavily in human resource management, such as corporate culture and employee training, which may not guarantee an expected result. In addition, it is not advisable to have a transformation project that aims at transforming every periphery member into a semi-core members because there must be some, or even many, periphery members of the firm who do not share any of the firm's aspiration and their reasons for joining the firm might be simply that they did not have an preferred alternative so that they chose the firm just as a temprory place to stay. 
In such a situation, it does not pay to invest in aim of transforming them.

It is worth noting that the transformation is not an easy task to accomplish. Many people join a firm due to economic and career considerations and they will switch to other firms if a better job offer or career prospect is available to them. Therefore, it is hard to retain those people even if the firm has good corporate culture and human resource management system. However, there seems to be a solution to the retention of talented people, i.e., the employee stock plan. Giving the employees the entitlement to the firm's stock can be an effective way of transforming them into stable and loyal members of the firm because through sharing the firm's stocks with the employees the firm can establish strong shared interests and sense of belonging among its employees. Some people may argue that it is an expensive solution as the current shareholders of the firm will have to let go some parts of their stockholdings. However, there are two things to consider if such a letting-go is worthwhile. One is that there is a cost-benefit analysis because the employee stock plan will result in gains from the productivity improvement because the employees may pursue consummate rather than perfunctory performance with intrinsic motivation after they are turned into stockholding-employees. The other is that there will be less capital-labor conflicts that may cost a lot because the labor-employees are now also shareholder-employees.

\subsection{The competitive advantage of the firm}

The TCE explains the competitive advantage of the firm in terms of its capabilities to reduce or economize on transaction costs (Williamson, 1991a, 1991b) while the RBV sees the source of competitive advantage as the value-creating internal resources the firm owns and controls. Both views are insightful yet partial as competitive advantage is often manifested itself by a superior value/cost ratio, which means both cost and value aspects need to be considered when it comes to competitive advantage.

As it is often argued that the RBV/KBT offers a more convincing account on the competitive advantage of the firm, it is worth making a critique of the RBV argument here.

According to Penrose (1959), the firm can be seen as a collection of resources. The followers of Penrose further argue that a firm's sustained competitive advantage (SCA) derives from its firm-specific assets/resources that are 'valuable, rare, inimitable, and unsubstitutable' (VRIN) (Barney, 1991). In the strategy literature, the RBV scholars have identified all sorts of SCA-generating resources, such as corporate culture (Barney, 1986b), organizational routines (Peteraf, 1993), core competence (Prahalad and Hamel, 1990), causally ambiguous competence (Reed and DeFillippi,1990), intangible resources and capabilities (Hall, 1993), human resource management system (Lado and Wilson, 1994), dynamic capabilities (Teece et al., 1997), and trustworthy reputation (Dyer and Chu, 2003), among others. Although abovementioned resources are very valuable, we argue, the firm actually does not own any resources and the ultimate competitive advantage does not derive from the ownership of resources but the relationship with the resource-holders. The ACT submits that the quality of the relationship with the firm's various resource-holders is in turn determined by two factors: the firm's aspirations and its relationship management.

The firm does not own any resources 
Lavie (2006) points out that the RBV is based on the assumption that firms are heterogeneously endowed with idiosyncratic resources that are owned or controlled within their boundaries. However, this ownership and control view is an imprecise analysis if one considers the 'legal fiction' view of the firm of Jensen and Meckling (1976), according to whom, most organizations are simply legal fictions which serve as a nexus for a set of contracting relationships among individuals who hold their resources. Here, the individuals involved in the nexus of contracts are the real owners or providers of resource of all kinds. For example, the shareholders are the owners or providers of financial resources; the employees are the owners and providers of their labors, be it manual or intellectual; the suppliers are the owners and providers of materials or services supplied; and so on.

In such a nexus of contracts, the firm as a 'legal fiction' does not actually own any resources. The firm does not own any employees although it has large degree of authority on how to use the labors of the employees. The firm also does not own any financial resources because all financial assets are simply equity belonging to the shareholders. The so-called retained profits are simply undistributed dividends to the shareholders who in turn have the ultimate ownership.

Arguably, the firm also does not own knowledge as knowledge ultimately resides only in human brains that the firm does not own. Although many scholars, following Nelson and Winter (1982), have taken a collectivist perspective to knowledge and argue for organization-level social knowledge (e.g., Spender, 1996; Kogut and Zander, 1992; Nahapiet and Ghoshal, 1998), no one can deny that, in an extreme situation when the entire employment of a firm is replaced by a new set of employees, the so-called organizational routines will be changed and become very different from those of the original. Simply put, organizational routines are not static but dynamic, depending on and evolving with the change of the people who practice them. Therefore, if the firm does not own the people who practice the evolving organizational routines, the firm cannot own the organizational routines either.

\section{Ownership of resources vs. relationship with resource-holders}

According to Penrose (1959: 78), 'the services that the resources', including physical, human, managerial and entrepreneurial, 'will yield depend on the capacities [italic added] of the men using them'. We see two types of capacities here, one being the relational capacity while the other the technical capacity. The relational capacity refers to the capacity of the entrepreneur or management to maintain a good relationship with the resource holders within the firm's boundary so that the resource holders will be willing to work productively for the firm. The technical capacity refers to the capacity of the entrepreneur and management to utilize the resources at their full productivities. Of these two capacities, the relational capacity is more important than the technical capacity for the following reason. If the entrepreneur or management has high relational capacities but low technical capacities, the entrepreneur or management can still rely on the employees to self-govern their own works; in other words, decentralization under good firmemployee relationships can still work well. However, if the entrepreneur or management has high technical capacities but low relational capacities, then while technically capable entrepreneur or management wishes to centralize decision making, the employees may not be willing to work wholeheartedly for the firm, and the result will be lower overall 
performance.

The determinants of the quality of the relationship

The ACT claims that a strong aspiration owned by the firm (or its founders) is one the two determinants of the quality of the relationship with the firm's various resourceholders. A strong and attractive aspiration may be something more than mere profitseeking. A strong aspiration may have the power to attract like-minded people sharing the same aspirations and transform those who initially do not share such aspirations into likeminded people sharing the same or some part of the aspirations of the firm. In this regard, transformational leaders (Bass, 1985; Burns, 1978) are of instrumental importance for the tasks of transforming the employees.

However, aspiration alone may not be sufficient. Good relationship management is another important factor. The ACT sympathizes with the argument of the stakeholder theory and see good management of relationships with stakeholders as an important source of the firm's competitive edge because good relationships may result in both low transaction costs and high value creation (Dyer, 1997; Li, 1998; Dyer and Chu, 2003). To maintain good relationships with stakeholders, the firm has to implement a fair mechanism for wealth distribution among all stakeholders involved. Only when all stakeholders/parties who have contributed to the wealth generation are fairly rewarded, they will feel satisfactory and the relationships in question will be in good quality. The stakeholder satisfaction is very important for sustainable wealth generation. Take employee for example, only when the employees are satisfactory about their employer, will they work committedly, productively and creatively as reciprocity. In a sense, the employees' commitment, productivity and creativity are the root source of the competitive advantage of the firm.

\section{Discussion and conclusion}

\section{The purpose of the firm}

An understanding of the purpose of the firm will have important managerial implications. The 'nexus of contracts' view of the firm argued by Jensen and Meckling's (1976) seems to imply that the firm as a 'legal fiction' has no purpose other than a connection of a web of contractual relationships. The most popular view might be the profit maximization argument that views the sole purpose of the firm as to maximize profits for the firm's shareholder. In Friedman's (1970) opinion, there is no any social responsibility/purpose other than maximizing shareholders' value.

We do not buy into such an economistic view. Such a profit maximization view is unrealistic as Simon (1955) points out that the real behaviors of agents will be satisficing rather than maximizing. In addition, such a profit maximization view may have a selffulfilling propensity, namely, the more one believes it true, the more he will practice in accordance with that view, and therefore, the more he will believe it is true.

The ACT implies that the firm does have a social purpose of aspiration pursuing, in addition to profit seeking. The firm is initiated by the entrepreneur who gets an entrepreneurial idea/aspiration or recognizes an entrepreneurial opportunity and then starts to pursue such an aspiration through the firm he established as an aspirational community that also meets the social needs of people with similar aspirations. If 
managers of any firm sympathize with this social purpose view, they should try to manage their firm in a way to give the priority to the pursuit of an entrepreneurial aspiration with a social purpose over the maximization of profit.

\section{A model of aspirational man}

Scholars have made several models of man, such as 'economic man', 'social man', 'selfactualizing man', and 'complex man'. The ACT is based on an assumption that human being is an 'aspirational man' who, besides other needs, has aspirations or the need of self-actualization (Maslow, 1943). Human aspirations may be of economic, social or/and other kinds. For many aspirations, it is unlikely that a person alone can realize them (cf. Simon, 1957: 199) and therefore the aspirational people do need some aspirational communities to be associated with in order to pursue those aspirations together with the other people sharing similar or same aspirations. The managerial implication of the model of aspirational man is that the firm's management should also care about whether the employees share the firm's aspirations as well as the other way around, i.e., the firm should also care about whether the firm can help the individual employees actualizing their own aspirations.

\section{Economic efficiency}

The ACT claims that, if the market is sufficiently effective and efficient for allocating contractual labor, it is less effective for allocating aspirational labor. To remedy this problem, the firms steps in to act as an effective mechanism for allocating, i.e., attacting, selecting, transforming and retaining, aspirational labor. Both the market and the firms complement rather than substitute to each other. The firm will attract people from the market, some of whom may share the same aspirations of the firm while some others may not. Some of the employees of the firm may become stable and loyal to the firm while some others will not for reasons on the part of either the firm or the employees. For those people who leave a firm, the market will be an efficient mechanism for them to find other firms to chase their aspirations. In this sense, the market and the firms working together will be the most effective and efficient system to allocate aspirational as well as contractual labors economy-wide. The ACT implies that only when the aspirational labors are efficiently allocated, will a win-win-win state be achieved, i.e., efficiency maximized at the individual, firm, and economy levels simultaneously.

In this paper, we have reviewed the existing three major theories of the firm, i.e., the transaction cost theory, knowledge-based theory and the entrepreneurship theory and highlighted the limitations and weaknesses of each of them. We acknowledge that all of the three theories are insightful yet partial because each of them has a particular focus on the multifaceted phenomenon of the firm. Toward a better understanding the nature and essence of the firm, we have proposed an aspirational community theory of the firm (ACT) as a way to integrate the existing theories. We also offer some managerial implications of the new theory. 


\section{Reference}

Alchian, A.A. \& Demsetz, H. 1972. Production, Information Costs and Economic Organization. American Economic Review, 62(5): 777-795

Alvarez, S.A. \& Barney, J.B. 2004. Organizing rent generation and appropriation: toward a theory of the entrepreneurial firm. Journal of Business Venturing, 19(5): 621-35

Addas, S. \& Pinsonneault, A. 2007. IT capabilities and firm performance: A resourcebased, alliance perspective. available at: http://ojs.acadiau.ca/index.php/ASAC/article/viewFile/1067/926

Asher, C.C., Mahoney, J.M. \& Mahoney, J.T. 2005. Toward a property rights foundation for a stakeholder theory of the firm. Journal of Management and Governance, 9(1):5-32

Barney, J.B. 1986a. Strategic Factor Markets: Expectations, Luck, and Business Strategy. Management Science, 32(10): 1231-1241.

Barney, J.B. 1986b. Organizational Culture: Can It Be a Source of Sustained Competitive. Advantage?. Academy of Management Review, 11(3), 656 - 665

Barney, J.B. 1991. Firm Resources and Sustained Competitive Advantage. Journal of Management, 17(1): 99-120

Barney, J.B. 1996. The resource-based theory of the firm. Organization Science, 7(5): 469

Barney, J. 2001. Is the resource-based "view" a useful perspective for strategic management research? Yes. Academy of Management Review, 26(1): 41-56

Bass, B.M 1985) Leadership and performance beyond expectations, New York: Free Press

Burns, J.M, 1978) Leadership, New York: Harper and Row

Cantillon, R. 1775) Essai sur la nature de commerce en general. Henry Higgs, ed. London: Macmillan, 1931

Casson, M. 1982) The Entrepreneur: An Economic Theory. Oxford: Martin Robertson

Casson, M. 2000. An Entrepreneurial Theory of the Firm. in Foss N, \& Mahnke V (eds), Competence, Governance, and Entrepreneurship, Oxford University Press, pp 116146

Casson, M. 2005. Entrepreneurship and the theory of the firm. Journal of Economic Behavior and Organization, 58: 327-348

Chamberlin, E.H. 1933) Theory of Monopolistic Competition. Cambridge, MA: Harvard University Press

Coase, R.H. 1937. The Nature of the Firm. Economica, New Series, 4(16): 386-405

Coase, R.H. 1972. Industrial Organization: A proposal for research. in Ronald H. Coase., The Firm, the Market, and the Law. Chicago: University of Chicago Press, 1988, pp. $57-74$

Coase, R.H. 1988. 'The Nature of the Firm: Influence. Journal of Law, Economics, and Organization, 4(1): 33-47

Collis, D.J. \& Montgomery, C.A. 1995. Competing on resources, Strategy in the 1990s. Harvard Business Review, 73 (July-August):118-128

Conner, K., 1991. A historical comparison of resource-based theory and five schools of thought within industrial organization economics: Do we have a new theory of the firm?'. Journal of Management, 17(1): 121-154.

Conner, K.R. \& Prahalad, C.K. 1996. A resource-based theory of the firm: Knowledge 
versus opportunism. Organization Science, 7: 477-501

Debreu, G. 1959) Theory of Value. New York: Wiley

Dew, N., Velamuri, S.R. \& Venkataraman, S. 2004. Dispersed knowledge and the entrepreneurial theory of the firm. Journal of Business Venturing, 19(5): 659-79

Donaldson, T. \& Preston, L.E. 1995. The Stakeholder Theory of the Corporation: Concepts, Evidence, and Implications. Academy of Management Review, 20(1): 6591

Dyer, J.H. 1996. Does governance matter? Keiretsu alliances and asset specificity as sources of Japanese competitive advantage. Organization Science, 7(6): 649-666

Dyer, J.H. 1997. Effective interfirm collaboration: How firms minimize transaction costs and maximize transaction value. Strategic Management Journal, 18(7): 535-556

Dyer, J.H. \& Chu, W. 2003. The Role of Trustworthiness in Reducing Transaction Costs and Improving Performance: Empirical Evidence from the United States, Japan, and Korea. Organization Science, 14(1): 57-68

Evan, W.M. \& Freeman, R.E. 1988. A Stakeholder Theory of the Modem Corporation: Kantian Capitalism. in Beauchamp, T.L. \& Bowie, N. (eds.), Ethical Theory and Business, third edition, Englewood Cliffs, NJ: Prentice Hall

Fama, E. F. 1980. Agency Problems and the Theory of the Firm. Journal of Political Economy, 88(2): 288-307

Felin, T. \& Foss, N.J. 2005. Strategic organization: a field in search of micro-foundations. Strategic Organization, 3: 441-455.

Felin, T. \& Hesterley, W.S. 2007. The knowledge-based view, nested heterogeneity, and new value creation: philosophical considerations on the locus of knowledge,' Academy of Management Review, 32: 195-218

Foss, K., Foss, N.J. \& Klein, P.G. 2007. Original and Derived Judgment: An Entrepreneurial Theory of Economic Organization. Organization Studies, 28(12): 1893-1912

Foss, K. Foss, N.J., Klein, P.G. \& Klein, S.K. 2007. The entrepreneurial organization of heterogeneous capital. Journal of Management Studies, 44(7): 1165-1186

Foss, N.J. 1993. Theories of the Firm: Contractual and Competence Perspectives. Journal of Evolutionary Economics, 3: 127-144

Foss, N.J. 1994. The theory of the firm: the Austrians as precursors and critics of contemporary theory. Review of Austrian Economics, 7(1): 31-65

Foss, N. J. 1996. Knowledge-based approaches to the theory of the firm: some critical comments. Organization Science, 7: 470-476.

Foss, N.J. 1997. Austrian insights and the theory of the firm. Advances in Austrian Economics, 4: 175-98

Foss, N.J. 1998. The theory of the firm: an introduction to themes and contributions. (ISBN: 87-7869-026-9), paper prepared as the introductory chapter in Nicolai Foss, (eds.), 1999. Theories of the Firm: Critical Perspectives in Economic Organization (3 vols.), London: Routledge

Foss, N.J. 1999. Research in the Strategic Theory of the Firm: 'Isolationism' and'Integrationism. Journal of Management Studies, 36(6): 725-755

Foss, K., Foss, N., \& Klein, P.G. 2007. Original and derived judgment: An entrepreneurial theory of economic organization. Organization Studies, 28(12): 18931912

Foss, N.J. \& Klein, P.G. 2005. Entrepreneurship and the theory of the firm: any gains 
from trade?'. In Alvarez, S.A. et al. (Eds), Handbook of Entrepreneurship Research: Disciplinary Perspectives. New York: Springer.

Freeman, R. E. 1984. Strategic Management: A stakeholder approach, Boston: Pitman

Friedman, M. 1970. The Social Responsibility of Business is to Increase its Profits. New York Times Magazine, September 13, 1970

Ghoshal, S. \& Moran, P. 1996. Bad for Practice: A Critique of the Transaction Cost Theory. Academy of Management Review, 21(1): 13-47

Grant, R.M. 1996a. Toward a Knowledge-Based Theory of the Firm. Strategic Management Journal, 17(Winter Special Issue): 109-122.

Grant, R.M. 1966b. Prospering in dynamically competitive environments: Organizational capability as knowledge integration. Organization Science, 7: 375-387

Grossman, S.J. \& Hart, O.D. 1986. The costs and benefits of ownership: A theory of vertical and lateral integration. Journal of Political Economy, 94(4): 691-719

Hall, R. 1993. A Framework Linking Intangible Resources and Capabilities to Sustainable Competitive Advantage. Strategic Management Journal, 14 (8): 607-618

Hart, O. 2008. Economica Coase Lecture: Reference points and the theory of the firm. Economica, 75(299): 404-411

Hart, O. \& Moore, J. 1990. Property Rights and the Nature of the Firm. Journal of political economy, 98(6): 1119-1158

Hart, O. \& Moore, J. 2008. Contracts as reference points. Quarterly Journal of Economics, (2008) 123 (1): 1-48

Higgins, E.T. 1998. Promotion and prevention: Regulatory focus as a motivational principle. in Zanna, M.P. (eds), Advances in experimental social psychology, vol. 30: 1-46. New York: Academic Press

Hodgson, G.M. 2004. Opportunism is not the only reason why firms exist - why an explanatory emphasis on opportunism may mislead management strategy. Industrial and Corporate Change, 13(2): 401-418

Jackson, S.E., Joshi, A.J. \& Erhardt, N.L. 2003. Recent Research on Team and Organizational Diversity: SWOT Analysis and Implications. Journal of Management, 29(6): 801-830

Jensen, M.C. \& Meckling, W.H. 1976) 'Theory of the firm: Managerial behavior, agency cost and ownership structure. Journal of Financial Economics, 3: 305-360

Kaplan, S., Schenkel, A., von Krogh, G., \& Weber, C. 2001. Knowledge-based theories of the firm in strategic management: A review and extension. Working paper No. 421601, Massachusetts Institute of Technology, Boston.

Katz, R.,T. \& Allen, J. 1982. Investigating the Not Invented Here (NIH) syndrome: A new look at the performance, tenure, and communication patterns of $50 \mathrm{R} \& \mathrm{D}$ project groups. $\boldsymbol{R} \& \boldsymbol{D}$ Management, 12(1): 88-115

Kirzner, I.M. 1979) Perception, Opportunity and Profit, Chicago: University of Chicago Press

Klein, B. 1983. Contracting costs and residual claims: The separation of ownership and control. Journal of Law and Economics, 26(2): 367-374

Knight, F.H. 1921) Risk, Uncertainty, and Profit. New York: Augustus M. Kelley

Kogut, B. \& Zander, U. 1992. Knowledge of the firm, combinative capabilities, and the replication of technology. Organization Science, 3(3): 383-397.

Kogut, B. \& Zander, U. 1993. Knowledge of the firm and the evolutionary theory of the 
multinational corporation. Journal of International Business Studies, 24: 625-645

Kogut, B. \& Zander, U. 1996. What firms do? Coordination, identity and learning,' Organization Science, 7: 502-518

Lado, A, \& Wilson, M. 1994. Human resource systems and sustained competitive advantage: a competency based perspective. Academy of Management Review, 19: 699-727

Langlois, R.N. 1988. Economic change and the boundaries of the firm. Journal of Institutional Theoretical Economics, 144: 635-57

Langlois, R.N. 2005. The entrepreneurial theory of the firm and the theory of entrepreneurial firm. Working Paper 2005-27R, Department of Economics, University of Connecticut, USA.

Lavie, D. 2006. The competitive advantage of interconnected firms: An extension of the resource-based view. Academy of Management Review, 31(3): 638-658

Li, P.P. 1998. Toward a Geocentric Framework of Organizational Form: A Holistic, Dynamic and Paradoxical Approach. Organization Studies, 19 (5): 829-861

Madhok, A. 1996. The organization of economic activity: transaction costs, firm capabilities and the nature of governance. Organization Science, 7: 577-590

Malmgren, H.B. 1961. Information, Expectations and the Theory of the Firm. Quarterly Journal of Economics, 75(3): 399-421.

Marschak, J. \& Radner, R. 1972) Economic Theory of Teams. New Haven and London: Yale University Press

Maslow, A.H. 1943. A Theory of Human Motivation. Psychological Review, 50(4): 37096

Masten, S.E., Meehan, J.W. Jr., \& Snyder, E.A. 1991. The Costs of Organization. Journal of Law, Economics, \& Organization, 7(1): 1-25

Mathews, J.A. 2002) Dragon multinational: A new model of global growth, Oxford University Press: New York

Nahapiet, J. \& Ghoshal, S. 1998. Social capital, intellectual capital and the organizational advantage. Academy of Management Review, 23: 242-266

Nelson, R.R. \& Winter, S.G. 1973. Toward and evolutionary view of economic capabilities. American Economic Review, 63(2): 440-449

Nelson, R.R. \& Winter, S.G. 1982) An Evolutionary Theory of Economic Change. Cambridge, MA: Harvard University Press

Nickerson, J.A. \& Zenger, T.R. 2004. A knowledge-based theory of the firm - the problem-solving perspective. Organization Science, 15: 617-632

Penrose, E. T. 1959) The Theory of the Growth of the Firm, Oxford: Basil Blackwell.

Penrose, E. T. 1995. Foreword to the third edition. in The Theory of the Growth of the Firm, third edition, Oxford: Oxford University Press, pp. viv-xxi

Peteraf, M.A. 1993. The cornerstones of competitive advantage: A resource-based view. Strategic Management Journal, 14(3): 179-191

Pfeffer, J. 1994) Competitive advantage through people: Unleashing the power of the work-force. Boston: Harvard Business School Press.

Porter, M.E. 1991. Toward a Dynamic Theory of Strategy. Strategic Management Journal, 12(S2): 95-117

Prahalad, C.K. \& Hamel, G. 1990. The core competence of the corporation. Harvard Business Review, 68(3): 79-91. 
Reed, R. \& DeFillippi, R.J. 1990. Causal ambiguity, barriers to imitation, and sustainable competitive advantage. Academy of Management Review, 15(1), pp. 88-102

Richardson, G. B. 1972. The Organisation of Industry. The Economic Journal, 82(327): 883-896

Robinson, J. 1933) The Economics of Imperfect Competition. London: MacMillan Press

Ross, S.A. 1973. The economic theory of agency: The principal's problem. American Economic Review, 63(2): 134-139

Schilling, M.A. 2000. Decades ahead of her time: advancing stakeholder theory through the ideas of Mary Parker Follett. Journal of Management History, 6(5): $224-242$

Schumpeter, J.A. 1934) The Theory of Economic Development, Cambridge: Harvard University Press

Silver, M. 1984) Enterprise and the Scope of the Firm: The Role of Vertical Integration, Oxford: Martin Robertson and Company Ltd

Simon, H.A. 1951. A formal theory of the employment relationship. Econometrica, 19(3): 293-305

Simon, H.A. 1955. A behavioral model of rational choice. Quarterly Journal of Economics, 69, 99-118

Simon, H.A. 1957) Models of Man: Social and Rational. New York: John Wiley \& Sons. Simon, H.A. 1995. Organizations and markets. Journal of Public Administration Research and Theory, 5(3): 273-294

Spender, J.-C. 1996. Making knowledge the basis of a dynamic theory of the firm,' Strategic Management Journal, 17(Winter Special Issue): 45-62.

Teece, D., Pisano, G., \& Shuen, A. 1997. Dynamic Capabilities and Strategic Management. Strategic Management Journal, 18(7): 509-533

Venkataraman, S. 1997. The distinctive domain of entrepreneurship research. Advances in Entrepreneurship, Firm Emergence and Growth, vol. 3. JAI Press, Greenwich, CT, pp. 119-138.

Weber, L. \& Mayer, K.J. 2011. Designing effective contracts: exploring the influence of framing and expectations. Academy of Management Review, 36(1): 53-75.

Weber, L., Mayer, K.J. \& Macher, J.T. 2011. An Analysis of Extendibility and Early Termination Provisions: The Importance of Framing Duration Safeguards. Academy of Management Journal, 54(1): 182-202.

Wernerfelt, B. 1984. A resource-based view of the firm. Strategic Management Journal, 5: $171-180$

Williamson, O.E. 1971. The vertical integration of production: Market failure considerations. American Economic Review, 61(2): 112-123

Williamson, O.E. 1975) Markets and Hierarchies: Analysis and Antitrust Implications. New York: Free Press

Williamson, O.E. 1985) The Economic Institutions of Capitalism, New York: Free Press Williamson, O.E. 1991a. Strategizing, Economizing, and Economic Organization,' Strategic Management Journal, 12 Winter Special Issue): 75-94

Williamson, O.E. 1991b. Comparative Economic Organization: The Analysis of Discrete Structural Alternatives,' Administrative Science Quarterly, 36(2): 269- 296

Williamson, O.E. 1999. Strategy research: Governance and competence perspectives. Strategic Management Journal, 20(12): 1087-1108

Winter, S.G. 1995. Four Rs of profitability: rents, resources, routines, and replication. In 
Montgomery, C.A. (eds.), Resource-based and evolutionary theories of the firm: towards a synthesis, Norwell (MA): Kluwer Academic Publishers, pp. 147-178.

Witt, U. 1999. Do entrepreneurs need firms? A contribution to a missing chapter in Austrian economics. Review of Austrian Economics, 11(1-2): 99-109.

Witt, U. 2001. Changing cognitive frames - changing organizational forms: an entrepreneurial theory of organizational development. Industrial and Corporate Change, 9(4): 733-755

Zajac, E.J. \& Olsen, C.P. 1993. From transaction cost to transactional value analysis: Implications for the study of interorganizational strategies. Journal of Management Studies, 30(1): 131-145

Zander, I. 2007. Do You See What I Mean? An Entrepreneurship Perspective on the Nature and Boundaries of the Firm. Journal of Management Studies, 44(7): 11411164

\section{NOTES}

\footnotetext{
i Note that although the singular form 'theory' is used here, each of the three theories is not a single unified theory but a set of various interpretations that shar a core logic. For convenience purpose only, we use the singular form throughout the paper.

${ }^{\text {ii }}$ We use shared aspiration and shared vision interchangeable throughout the paper. For convenience purpose, we only use the word 'aspiration' rather than 'aspiration/vision' for most of the time.
} 